\title{
Ability of wild rabbit, Oryctolagus cuniculus, to lactate successfully in hot environments explains continued spread in Australia's monsoonal north
}

\author{
B. D. Cooke A,C $^{\mathrm{A}}$ M. Brennan ${ }^{\mathrm{B}}$ and P. Elsworth ${ }^{\mathrm{B}}$ \\ A Institute for Applied Ecology, University of Canberra, Bruce, ACT 2617, Australia. \\ ${ }^{B}$ Department of Agriculture and Fisheries, PO Box 102, Toowoomba, Qld 4350, Australia. \\ ${ }^{\mathrm{C}}$ Corresponding author. Email: brian.cooke@canberra.edu.au
}

\begin{abstract}
Context. European rabbits evolved in Spain and Portugal and are adapted to winter-rainfall Mediterranean habitats. On introduction into Australia in 1859, wild rabbits quickly colonised similar habitats across the southern two-thirds of the continent. However, over the past 40 years, they have spread further into monsoonal savanna habitats in northern Queensland.

Aims. To explain this, we considered adaptive responses of wild rabbits to hot conditions, particularly potential mechanisms for reducing the heat load of lactation, which has been identified as a likely limiting factor.

Methods. We analysed data from captive wild rabbits to identify mechanisms that could potentially reduce lactational heat load, and obtained data from shot samples of wild rabbits from northern Queensland to determine which of these might be most important in the field.

Key results. Rabbits spread food intake evenly across the 20-day lactation period and under hot conditions, captive wild individuals used body reserves to meet energy requirements for lactation, which is more energy efficient than converting digestible foods to milk.

Conclusions. This strategy reduces the heat load of lactation, enabling rabbits to suckle young successfully under hot conditions, but it comes at a cost. Rabbits need extra body reserves before breeding and need to regain those reserves between litters.

Implications. The slow spread of rabbits into Australia's monsoonal savannas is likely to continue, given the rabbit's reproductive flexibility and further natural selection for breeding in this environment.
\end{abstract}

Additional keywords: energetics, heat-dissipation limit.

Received 6 December 2017, accepted 18 March 2018, published online 5 June 2018

\section{Introduction}

Lagomorphs, namely rabbits, hares and pikas, are a worldwide order of mammals with representative species in most climatic zones from the Arctic to tropical parts of Africa and Central and South America (Flux 1981). Arctic and snowshoe hares (Lepus articus and Lepus americanus) show adaptations to cold habitats, being well insulated, whereas jack-rabbits (Lepus alleni) are physiologically adapted to live in hot desert regions (Dawson and Schmidt-Nielsen 1966), with breeding patterns showing parallel adaptations. Within the genus Lepus, a single large litter per annum is produced by Arctic hares, whereas tropical hares produce several small litters during the year, although net productivity between these species is similar (Flux 1981).

European rabbits (Oryctolagus cuniculus) initially evolved in the Mediterranean climatic region of the Iberian Peninsula and are adapted for maximising production of young by producing a litter each month during the winter-spring pasture-growing season (Soriguer 1981; Tablado et al. 2009). This is facilitated by an immediate postpartum oestrus and the ability to maintain successive 28-day pregnancies while lactating.

In Australia, where European rabbits have been introduced, they normally produce four to six successive litters each of about five young (range 2-9) during the cooler months. The number of litters is dependent on the duration of autumn-spring pasture growth, which varies regionally across southern Australia depending on soil moisture, temperature and pasture type (Gilbert et al. 1987).

Although rabbits are widespread in southern Australia, they are generally confined to the southern two-thirds of the continent. Distribution is limited because, in the tropical north of Australia, monsoonal rains fall mainly in summer and highquality green food that rabbits require for efficient breeding is usually plentiful only during the hot, humid season. Under these 
conditions, rabbits are thought to be unable to dissipate the extra heat load generated in producing milk (Cooke 1977).

Although well recognised as a concept limiting domestic animal production in hot regions (West 2003; Finocchiaro et al. 2005), the idea that the energetics of milk production might limit the distributions of wild animals is only slowly being acknowledged. Król and Speakman (2003) proposed a 'heat dissipation limit hypothesis' that suggests that productivity is limited by the ability of mothers to dissipate heat associated with milk production. Their experiments mainly involved laboratory mice (Mus musculus). More recently, Guillemette et al. (2009) showed that lactating squirrels (Tamiasciurius hudsonicus) experiencing high heat load preferred less insulated nests, which implies a behavioural mechanism to help dissipate the excess heat produced during lactation.

Resting domestic laboratory rabbits respond to increases in ambient temperature from $5^{\circ} \mathrm{C}$ to $35^{\circ} \mathrm{C}$, initially by changing their thermal conductance, especially by altering blood flow to the ears to conserve or dissipate heat (Gonzalez et al. 1971; Kluger 2012). Panting begins only when ambient temperature exceeds $27^{\circ} \mathrm{C}$. Humidity further complicates heat loss by reducing the capacity to lose heat by evaporation, even with increased respiratory rate (Kasa and Thwaites 1990). In very hot atmospheres, rabbit body temperature rises from $39^{\circ} \mathrm{C}$ towards $41^{\circ} \mathrm{C}$, to increase heat loss by conductance, as well as by panting. The rabbit's respiration rate can exceed 500 shallow breaths a minute to avoid a temperature rise towards a lethal $42^{\circ} \mathrm{C}$ (Kasa and Thwaites 1990).

Wild rabbits seldom use water loss as a means of cooling and, generally, minimise heat stress and water loss by sheltering through the day in deep burrows where temperatures approximate mean daily temperature and the air is humid (Cooke 1990). Wild rabbits rarely drink; water requirements being met by selecting foods with adequate moisture content (Cooke 1982, 2014).

Given the physiology of non-reproductive rabbits, it is likely that the extra energy cost of lactation affects the rabbit's heat balance in tropical regions, especially where burrow temperatures are in excess of $27^{\circ} \mathrm{C}$. In this context, data from domestic rabbits show that milk yield is steady at ambient temperatures between $15^{\circ} \mathrm{C}$ and $23^{\circ} \mathrm{C}$, but falls sharply thereafter; milk production is markedly reduced as ambient temperature approaches $30^{\circ} \mathrm{C}$ (Parigi-Bini et al. 1992; Maertens et al. 2006).

When lactating, female wild rabbits eat $\sim 28 \%$ more food than normally (Cooke 2014) and conversion of digestible energy to milk energy occurs with an efficiency of $63 \%$ (Parigi-Bini et al. 1992). This means that lactating rabbits need to dissipate $10 \%$ more heat than do non-breeding rabbits, if the energy required for milk production is met from ingested nutrients alone. This is possible when ambient temperatures are low but increasingly difficult as temperature increases. From their worldwide review of data on breeding wild rabbits, Tablado et al. (2009) suggested that even with good-quality green food available, there is little effective breeding once mean ambient temperature exceeds $25^{\circ} \mathrm{C}$. However, because rabbits are scarce in extremely hot habitats, few studies in such localities have so far been conducted and this may limit the data available for review.
The need to look closely at the rabbit's physiological and geographical limits has been brought into sharper focus by efforts to compile an accurate map of the distribution of wild rabbits in Australia (D. Berman, pers. comm.). Observations in northern Queensland have indicated that, over the past 40 years, rabbits have not only become established, but have continued to extend their distribution. Wild rabbits reached the Atherton district of Queensland in 1980 (Stodart and Parer 1988) where, at $700 \mathrm{~m}$ above sea level, the cooler upland climate and high annual rainfall, averaging $1425 \mathrm{~mm}$, provides an environment similar to more southerly parts of Australia. Since then, rabbits have spread into drier savanna regions, extending $250 \mathrm{~km}$ west of Atherton through the Einasleigh Uplands, at least as far west as Georgetown (see Fig. 1), which has a mean annual rainfall of $819 \mathrm{~mm}$, most of which falls between December and March (southern hemisphere summer), whereas the mean minimum and maximum temperatures for November, the beginning of the 'wet season', are $21.8^{\circ} \mathrm{C}$ and $36.7^{\circ} \mathrm{C}$ respectively. Not only should a daily average temperature of over $29^{\circ} \mathrm{C}$ at the start of summer make it difficult for rabbits to maintain lactation, but the apparent expansion of rabbit distribution has occurred at a time when temperatures have been rising globally. This seems counter-intuitive, although not entirely unexpected, given that wild rabbits persist on some tropical islands (Flux and Fullagar 1992).

To gain some insight into the ways European rabbits are adapting to hot environments, we first review observations on the food intake of captive wild rabbits as they produce and raise litters of young. These observations were made in southern Australia in 1971-1972 and so can be taken as indicating the phenotypic flexibility of rabbit breeding patterns well before the recent spread of rabbits in northern Queensland. Second, several mechanisms that rabbits might use to reduce their heat load of lactation in the wild were considered. These ranged from reduced litter size to higher reliance on body energy reserves. To see which of these might be most important, we considered results from current field studies in tropical northern Queensland (Fig. 1).

Investigating how rabbits are overcoming climatic barriers to spread in northern Queensland is not just a question of academic importance. Rabbits are known agricultural pests and also cause major perturbations of natural ecosystems (Cooke 2013); thus, their further spread should be prevented if possible.

\section{Materials and methods}

\section{Observations on captive wild rabbits}

Observations were made on a small breeding colony of rabbits kept in an outdoor, cement-floored yard $5 \mathrm{~m} \times 5 \mathrm{~m}$ in Adelaide, South Australia. The colony consisted of two adult male rabbits, four adult females, and their young. All rabbits had been bred in captivity and were first-generation descendants of wild-caught rabbits from Belton $\left(32.247^{\circ} \mathrm{S}, 138.629^{\circ} \mathrm{E}\right)$ in north-eastern South Australia. Subadult rabbits were removed to prevent crowding and associated fighting.

The rabbits were provided with an artificial warren, under a roof to keep off rain and sun. The warren consisted of cement pipes of $18-\mathrm{cm}$ internal diameter that led to six insulated nest 


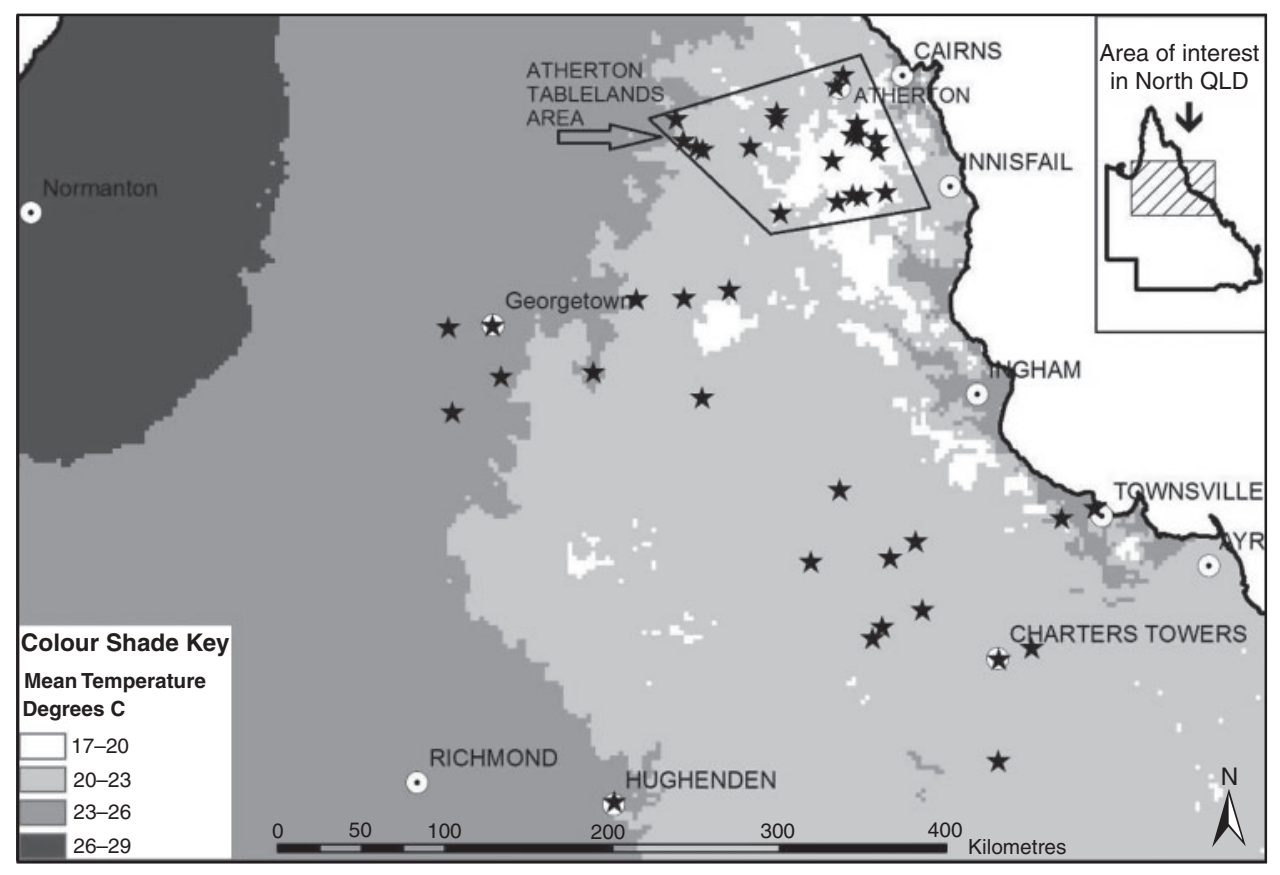

Fig. 1. Map of Queensland, showing present localities where rabbits are found (black stars) in relation to average annual temperature (data from Bureau of Meteorology). All known rabbit populations occur in regions where average annual rainfall is greater than $600 \mathrm{~mm}$ and occurs predominantly in summer.

boxes with removable lids so that both adult rabbits and young could be caught and monitored. Temperature within the nesting boxes generally varied by only $\pm 1.5^{\circ} \mathrm{C}$ throughout each day, although changing slowly, approximating mean monthly air temperature, as seasons progressed (data not shown).

Rabbits were provided with food pellets especially formulated as a complete diet for rabbits (Lauke Mills, Adelaide) and drinking water was provided $a d$ lib. Lucerne (alfalfa) hay was provided two or three times weekly, both for food and as a nesting material, and carrots were provided twice a week.

Female rabbits were caught and palpated regularly to determine their stage of pregnancy and to anticipate when they would give birth. Shortly before female rabbits produced litters, they carried lucerne hay into the chosen nest box and plucked belly fur to line the nest. Dyes of different colours rubbed onto each female's belly fur enabled nestlings and their respective mothers to be clearly identified.

Generally, nestlings were not handled nor was any attempt made to measure food intake for the first couple of days after birth. This reduced the risk that female rabbits might desert their young and allowed time for female rabbits to mate postpartum. Thereafter, a wire-mesh cage, $2 \mathrm{~m}^{2}$ in floor area, was moved into position in front of the appropriate nest-box entrance to confine the female rabbit. Shelter and separate dispensers for food pellets and water were provided in this cage and dry-matter intake was measured daily by weighing the dispensers (to the nearest gram) and correcting for the water content of air-dry pellets (11\%). Carrots and lucerne were not provided during lactation because of the difficulty of assessing the dry-matter intake. Usually, the doe was weighed, and then the kittens were weighed as a group every second day (also to the nearest gram). However, during short periods
(3-4 days), attempts were made to weigh both does and young before and immediately after daily feeding visits. This was done to estimate daily milk production. The weight of milk transferred was converted to volume assuming rabbit milk has a specific gravity of $1.041 \mathrm{~g}$ per $\mathrm{mL}$ (Bergman and Turner 1937). Kittens were removed promptly at weaning, to ensure that they did not eat pellets and invalidate measurement of female-rabbit food intakes.

\section{Field studies in northern Queensland}

Samples of rabbits were obtained every 3 months between June 2014 and September 2016, by shooting at night in two areas in northern Queensland. The first field site was north-west of Charters Towers $\left(20.077^{\circ} \mathrm{S}, 146.260^{\circ} \mathrm{E}\right)$ and the second near Atherton $\left(17.26^{\circ} \mathrm{S}, 145.486^{\circ} \mathrm{E}\right)$. The two sites represent extremes in the Einasleigh Uplands bioregion (Bastin 2008). Charters Towers is $\sim 310 \mathrm{~m}$ above sea level and has an annual rainfall of $664 \mathrm{~mm}$. Mean daily temperature range is from $22.4^{\circ} \mathrm{C}$ to $33.6^{\circ} \mathrm{C}$ (average minimum-average maximum) in January, the hottest month, and $11.5-24.8^{\circ} \mathrm{C}$ in July, the coldest month. Atherton is considerably wetter, with a mean annual rainfall of $1424 \mathrm{~mm}$, and because of the altitude of $700 \mathrm{~m}$, mean temperatures are generally milder: $18.8-28.4^{\circ} \mathrm{C}$ in January and $10.2-21.4^{\circ} \mathrm{C}$ in July. The vegetation around Charters Towers is savanna with scattered trees, whereas the Atherton area was originally covered in rainforest, but has since been cleared for agriculture and cattle production. The area of former rainforest quickly gives way to scrublands then open savanna to the west.

Each rabbit shot was sexed and bodyweight was recorded to the nearest $25 \mathrm{~g}$ before it was dissected and reproductive 
details were recorded. Female rabbits were considered pregnant if the ovaries showed recent ruptured follicles, implying that embryos were present but had not yet implanted $(<7$ days pregnant) or if there were visible embryos in utero. Numbers of implanted embryos were recorded and lactation was indicated if mammary tissues were well developed and milk could be expressed from the nipples. Breeding condition of females was subsequently categorised as sexually immature, pregnant but not lactating (mostly primiparous), pregnant and lactating, or lactating only. Male rabbits were regarded as sexually mature if testes had descended into the scrotum. Because of the low abundance of rabbits, sample sizes of rabbits shot were often small, particularly after being assigned to groups such as 'pregnant, not lactating' and, so, for some analyses, data were pooled.

\section{Results}

\section{Rabbit breeding in captivity}

Information was gained from six litters of young. Five litters were born in spring, the normal breeding season, but one litter was born late, during mid-summer. As the pattern of lactation of the mother of this litter was so different from the rest, it is discussed separately.

The most noticeable common feature of the five spring-time litters was that, contrary to expectations that the female rabbits would increase food intake as their litters grew, the pattern of food intake instead showed a rapid initial rise, then a plateau until about Day 20 when young first ventured from the nest (Fig. 2). The initial increase in food intake was roughly proportional to litter size, most likely because hormonal signals from corpora lutea or suckling stimulus from the young signalled the lactation load in advance (see example, Fig. 3).

Average bodyweight change of female rabbits during lactation was $+0.3 \mathrm{~g}$ per day (range from -5.1 to $+9.9 \mathrm{~g}$ per day). Because this was a small proportion of the rabbit total bodyweight, it suggested that rabbits must have met almost all lactation energy requirements from the food they ate.

An example of data for an individual rabbit is given in Fig. 3. This rabbit had two successive litters; the first of only two young

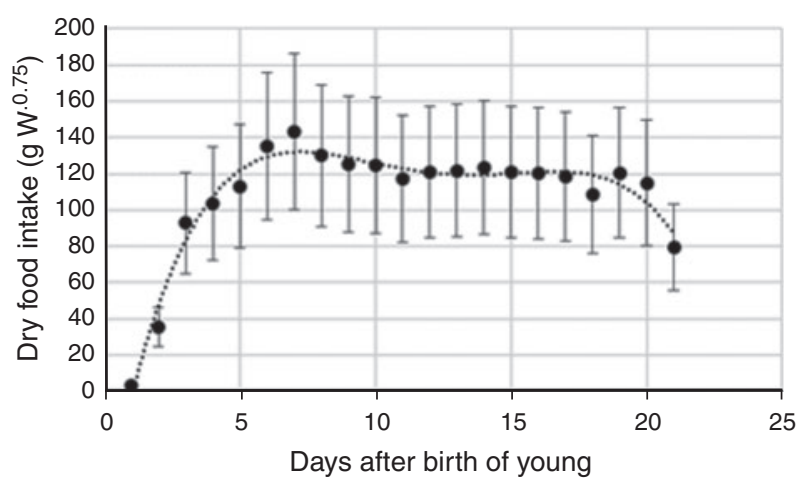

Fig. 2. Average daily food intake ( \pm standard deviation) for female rabbits feeding litters during the 20-day lactation period (excluding summer-born litter). Daily food intake was corrected for female bodyweight $\left(\mathrm{W}^{-0.75}\right)$ but not for litter size. Data for the first 3 days are based on fewer than five rabbits. Food intake rose only during the first week, then stayed constant until young were weaned 20 days later. and the second of four young. It was the only rabbit that mated and conceived immediately postpartum and was unperturbed when her second litter was weighed soon after birth. The figure shows the initial rapid rise in the mother's food intake, which remained elevated before slowly dropping away to normal maintenance levels after the first litter was weaned. The doe ate few pellets on the night the next litter of four was born, because she ate the placentas and other birth tissues. However, her food intake quickly increased to levels higher than those seen at the equivalent stage of lactation when she was feeding only two young. Food intake was then maintained at approximately the same level until the second litter of young was weaned and her daily food intake again began to decline towards the normal maintenance level (estimated to be $\sim 90 \mathrm{~g}$ per day).

In contrast to the litters of rabbits born in spring, the litter of eight young born in late December was raised successfully despite a mean temperature in the artificial warren of $24.2^{\circ} \mathrm{C}$ (Fig. 4). However, during lactation, the mother ate, on average, only $126 \mathrm{~g}$ dry-matter daily, whereas she had eaten $162 \mathrm{~g}$ daily in spring to rear six young when mean warren temperature was

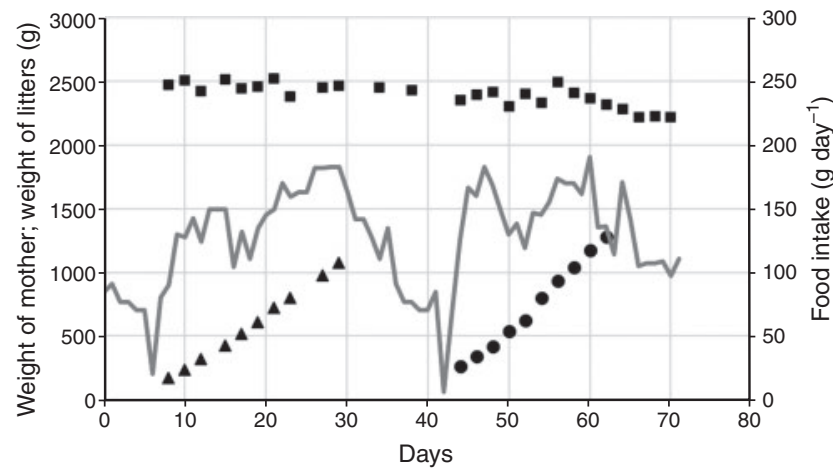

Fig. 3. Food intake (solid grey line) of a rabbit that raised two litters. Weight of doe (filled squares), first litter (2 young, filled triangles), and second litter (4 young, filled circles).

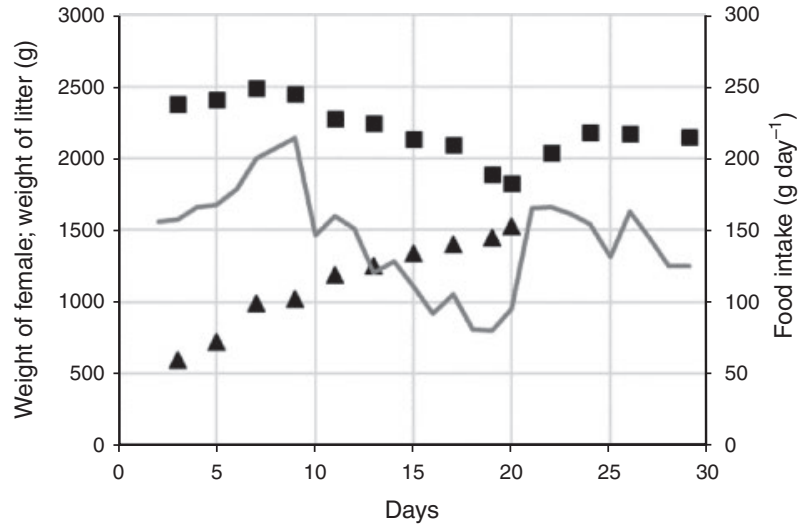

Fig. 4. Food intake of a rabbit (solid grey line) that raised a litter during hot weather in January (mid-summer) outside the normal breeding season. Weight of doe (filled squares), and litter of eight young (filled triangles). Note decline in food eaten and loss of bodyweight during lactation and return of female's appetite and recovery of bodyweight after young were weaned on the 20th day of lactation. 
17. $6^{\circ} \mathrm{C}$. Furthermore, her food intake declined rapidly after an initial peak in the first half of the lactation period. She was able to feed her young by using her body reserves, losing $670 \mathrm{~g}$ in weight (27\% of her maximum weight) over the course of lactation. The total weight of the litter at weaning was $1523 \mathrm{~g}$, compared with $1831 \mathrm{~g}$ for a litter of eight young raised by one of the other does in spring. As soon as the summer-born litter had been weaned, the mother's food intake increased dramatically, doubling over a few days, confirming that her depressed food intake was most likely associated with lactation.

Attempts to estimate the amount of milk produced daily by rabbits were largely unsuccessful. Only one female rabbit accepted handling and weighing well enough to enable measurement of milk production. The rabbit was allowed to feed the litter only once a day, as is common for wild rabbits (Hoy and Selzer 2010), and she spent only 3-4 min doing so. In that short time, an average of $90 \mathrm{~g}$ of milk or $88 \mathrm{~mL}$ was produced daily, averaged over 4 days. This equalled $22 \mathrm{~mL}$ of milk per day for each of the four young. Daily milk production was equivalent to $41 \mathrm{~g}$ per kg bodyweight; this lies well within the range (29-64 g per kg) of milk production seen in domestic rabbits (Maertens et al. 2006). Weighing the female rabbit rather than the young was the more reliable way of measuring milk production because young often urinated in the nest during or shortly after suckling.

\section{Field data from tropical Australia}

Female rabbits in northern Queensland appear to reach sexual maturity at a bodyweight of $1400 \mathrm{~g}$ (smallest pregnant rabbit); males mature between 1300 and $1550 \mathrm{~g}$ (Fig. 5).

Rabbits bred all year round at Atherton. Breeding was inhibited only near Charters Towers, probably as a result of the failure of the summer 'wet season' rains in 2015-2016. The average litter size (embryo count) for the two areas combined was 4.54 (range 4-7 young per litter). On the basis of pooled data from both sites, and taking $1400 \mathrm{~g}$ as the weight defining an adult rabbit, $34 \%$ of adult female rabbits were pregnant. Therefore, with pregnancy lasting 28 days, rabbits must have produced approximately $(34 \times 365) /(100 \times 28)=4.43$ litters per year or $\sim 4.43 \times 4.54=20.1$ young per female per year.

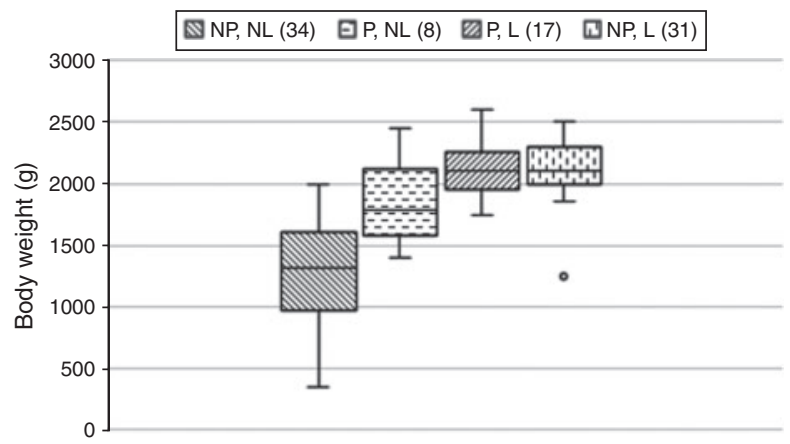

Fig. 5. Box-plots of female rabbit weights (data from Charters Towers and Atherton combined), showing means, standard deviations and ranges for nonreproductive rabbits (NP, NL), rabbits pregnant but not lactating (P, NL), pregnant and lactating rabbits $(\mathrm{P}, \mathrm{L})$ and rabbits not pregnant but lactating (NP, L). Numbers of rabbits in each category are shown in parenthesis. One rabbit was regarded as an outlier because of abnormally low body weight.

\section{Discussion}

Captive wild rabbits on a balanced diet raised litters of up to eight young without using body reserves in spring when burrow temperatures were between $17.6^{\circ} \mathrm{C}$ and $21.4^{\circ} \mathrm{C}$. Bodyweight losses or gains of female rabbits during lactation were small, generally in the order of $100-200 \mathrm{~g}$, or less than $5-10 \%$ of bodyweight. Although lactating female rabbits ate $\sim 28 \%$ more food than did caged male rabbits (Cooke 2014), they spread that extra food intake fairly evenly across the lactation period (Fig. 2). Food intake increased rapidly in the first 5 days after a litter was born, roughly in proportion to litter size, but then remained stable. There was no steady increase in food eaten to match the increasing energy requirements of the young. A similar, even food intake during lactation has also been found in domestic rabbits (Lebas 1987).

One female rabbit successfully raised a litter of eight young in mid-summer, after the other rabbits had stopped breeding. At weaning, the kittens had reached an average weight of $190 \mathrm{~g}$, well within the normal range for 20-day-old kittens (175-200 g, Myers 1958; Richardson and Osborne 1982). The female rabbit ate far less food than expected to support lactation and used body reserves to support milk production, losing $670 \mathrm{~g}$ in weight ( $27 \%$ of her maximum weight). Thus, apart from spreading food intake evenly across the lactation period, rabbits may also minimise the heat load of lactation by using body reserves. This is advantageous because body tissues are converted to milk energy with an efficiency of $76 \%$, whereas the conversion from digestible energy is only $63 \%$ efficient (Parigi-Bini et al. 1992).

Despite the small number of litters studied, our observations agree with other published information on rabbit lactation. For example, Rödel et al. (2015) showed that, in Germany, lactating and pregnant female rabbits spent $24 \%$ more time grazing than did pregnant females and $34 \%$ more time grazing than did non-reproductive females feeding on the same natural pasture. This agrees with the observation that breeding female rabbits in Australia ate $28 \%$ more food than did male rabbits (Cooke 2014). Rödel et al. (2015) also showed that lactating female rabbits spent similar amounts of time grazing irrespective of whether they were in early, mid- or late pregnancy. This too suggests that rabbits do not increase food intake during later phases of lactation. It is also well known from both wild and domestic rabbits that food intake does not always support lactation and body reserves are often used in maintaining milk output (Parigi-Bini et al. 1992; Rödel et al. 2015). Weight loss during lactation in highly productive domestic rabbits amounts to $32 \%$ of bodyweight (Parigi-Bini et al. 1992).

The constant food intake during the wild rabbit's lactation differs from the pattern described for European brown hare (Lepus europaeus), where the mother's food intake rises steadily over the first 3 weeks of the 4-week lactation period (Valencak et al. 2009). These different patterns between species reflect a complex of physiological adaptations associated with the rabbit's burrowing habit and its ability to persist in drier habitats, compared with hares whose young are reared above ground. Because young rabbits are in a thermally insulated, humid environment (a fur-lined, underground nest in which they urinate), milk can be energy- and protein-rich compared with that produced by animals whose young are exposed to 
variations in temperature and humidity and need milk with a higher water content to avoid dehydration.

In southern Australia, the adaptations described above enable rabbits to lactate and raise young under hot conditions, such as when rabbit breeding is initiated by pasture growth after heavy summer rains (Myers and Gilbert 1968; Wells et al. 2016). However, females usually produce only a single litter, presumably because, having used body reserves to feed their young, they need to recover those reserves before reproducing again.

Our observations in northern Queensland suggest that rabbits are similarly using body reserves for lactation rather than relying on food intake alone. Average pregnancy rates in northern Queensland were $34 \%$, but $44 \%$ of rabbits were classified as lactating only, implying that few rabbits returned to oestrus until they had fed their litters and regained bodyweight (Fig. 5). In southern Australia, the proportion of females not pregnant but lactating is much lower. For example, in a typical Mediterranean-like habitat at Urana in southern New South Wales $\left(35.32^{\circ} \mathrm{S}\right) 11.7 \%$ of female rabbits shot were lactating only, but at Mitchell in subtropical Queensland $\left(26.40^{\circ} \mathrm{S}\right)$, this rose to $27.4 \%$ (Myers 1971) and was clearly much higher in northern Queensland.

Rabbits in northern Queensland might be expected to have low bodyweights compared with those in southern Australia, because this might increase their surface area to weight ratio and help dissipate heat. However, the opposite was the case. Many female rabbits weighed over $2 \mathrm{~kg}$, the most likely reason being that a large body mass provides more reserves to support lactation.

Litter-size of rabbits in northern Queensland is low, averaging 4.54 kittens, but close to that of rabbits in other marginal habitats (e.g. 4.71 kittens at Mitchell in southern Queensland and 4.76 kittens at Tero Creek in north-western New South Wales (Gilbert et al. 1987)). This suggests that there is no strong trend towards reducing litter size to only two or three per litter as a means of further reducing the heat load of lactation. Annual production of young, estimated as $\sim 20$ young per year, is normal for marginal habitats. For subalpine, arid and subtropical habitats in Australia, annual production of young is estimated to be 15, 17 and 18 young per year respectively. By comparison, up to 38 young per year are produced in southern, winter-rainfall habitats (Gilbert et al. 1987).

Our behavioural observations and field data support the concept that the extra heat load of lactation is difficult for rabbits to dissipate when environmental temperature is high (Cooke 1977; Król and Speakman 2003; Guillemette et al. 2009). However, rabbits can at least partly circumvent the problem by spreading their food intake evenly across the lactation period and using body reserves to support lactation.

Wild rabbits clearly have greater physiological flexibility for coping with hot conditions than is generally recognised. Tablado et al. (2009) considered that, even with green feed available, rabbit breeding should be sharply curtailed as mean ambient temperature increases from $20^{\circ} \mathrm{C}$ to $25^{\circ} \mathrm{C}$. However, on the basis of the climate at Charters Towers, rabbits can clearly raise young close to this $25^{\circ} \mathrm{C}$ limit. In mid-summer, deep-burrow temperatures are likely to approach $27^{\circ} \mathrm{C}$ (mean daily temperature), but wild rabbits almost certainly reduce lactational heat stress by emerging at night, when average temperature falls to $\sim 22^{\circ} \mathrm{C}$. This can be implied because domestic rabbits lactate more efficiently when temperature varies daily than when temperature remains constant around the same mean (Maertens et al. 2006). Studies with lactating mice (Valencak et al. 2013) also showed that they can lactate more efficiently if allowed access to cage compartments held at lower temperatures than the nests where their litters were born.

Nonetheless, rabbits in northern Queensland are clearly living close to, if not on, their physiological limits. Spreading food intake and using body reserves for lactation account for some of their ability to adapt to hot climates; however, their continued spread into monsoonal savanna county since the 1980 s suggests that there are other underlying factors. Natural selection for greater heat tolerance is likely to have occurred. Rabbits in hot inland Australia have lighter-coloured fur and larger ears and different body proportions than do rabbits from cooler areas, presumably because of natural selection to increase heat reflectance and dissipation (Stodart 1965; Williams and Moore $1989 a, b)$.

In the future, rabbits may become more common or spread even further into Australia's monsoonal regions, beyond areas they currently occupy. This has serious implications not only because rabbits are agricultural pests but they are also a threat to mid-sized native mammals such as red-legged pademelons (Thylogale stigmatica), which inhabit remnant rainforest margins around Atherton, and rufous bettongs (Aepyprymnus rufescens), which occupy open savanna habitats. Not only might rabbits compete for available pasture but they may also support additional feral cats or facilitate the spread of introduced red foxes as predators (Cooke 2013). Consequently, there is not only some urgency to fully understand how rabbits are slowly adapting to tropical Australia, but also to find ways of preventing their spread.

\section{Conflicts of interest}

The authors declare no conflicts of interest.

\section{Acknowledgements}

We thank Joe Scanlan, Matt Amos and Cameron Wilson for their assistance in this study, comments on earlier drafts on the manuscript and preparation of the rabbit distribution figure. The experimental results include previously unpublished data from experiments conducted while B. Cooke was a recipient of a $\mathrm{PhD}$ scholarship from the Australian Wool Board (now Australian Wool Innovation). The experiments were non-intrusive and the food, water and living space provided for rabbits were acceptable by today's standards of animal welfare. P. Elsworth and M. Brennan provided information on the distribution and breeding biology of rabbits from an ongoing study in northern Queensland covered by Animal Ethics approval CA2013/07/709. Referees are thanked for comments that greatly improved the quality of the manuscript.

\section{References}

Bastin, G. (2008). 'Taking the Pulse.' (ACRIS Management Committee, National Land and Water Resources Audit: Canberra.)

Bergman, A. J., and Turner, C. W. (1937). The composition of rabbit milk stimulated by the lactogenic hormone. The Journal of Biological Chemistry 120, 121-127. 
Cooke, B. (1977). Factors limiting the distribution of the wild rabbit in Australia. Proceedings of the Ecological Society of Australia 10, $113-120$

Cooke, B. D. (1982). Reduction of food intake and other physiological responses to a restriction of drinking water in captive wild rabbits, Oryctolagus cuniculus (L.). Wildlife Research 9, 247-252. doi:10.1071/ WR9820247

Cooke, B. D. (1990). Rabbit burrows as environments for European rabbit fleas, Spilopsyllus cuniculi (Dale) in arid South Australia. Australian Journal of Zoology 38, 317-325. doi:10.1071/ZO9900317

Cooke, B. D. (2013). Rabbits: manageable environmental pests or participants in new ecosystems? Wildife Research 39, 279-289. doi:10.1071/WR11166

Cooke, B. D. (2014). Daily food intake of free-ranging wild rabbits in inland South Australia. Wildlife Research 41, 141-148. doi:10.1071/ WR14003

Dawson, T., and Schmidt-Nielsen, K. (1966). Effect of thermal conductance on the water economy of the antelope jack rabbit, Lepus alleni. Journal of Cellular Physiology 67, 463-471. doi:10.1002/jcp.1040670311

Finocchiaro, R., van Kaam, J. B., Portalano, B., and Misztal, I. (2005). Effect of heat stress on Mediterranean dairy sheep. Journal of Dairy Science 88, 1855-1864. doi:10.3168/jds.S0022-0302(05)72860-5

Flux, J. E. C. (1981). Reproductive strategies in the genus Lepus. In 'Proceedings of the World Lagomorph Conference', University of Guelph, Guelph, Canada. (Eds K. Myers and C. D. MacInnes.) pp. 155-174. (University of Guelph: Guelph, Ontario, Canada.)

Flux, J. E. C., and Fullagar, P. J. (1992). World distribution of rabbits on islands. Mammal Review 22, 151-205. doi:10.1111/j.1365-2907.1992. tb00129.x

Gilbert, N., Myers, K., Cooke, B. D., Dunsmore, J. D., Fullagar, P. J., Gibb, J. A., King, D. R., Parer, I., Wheeler, S. H., and Wood, D. H. (1987). Comparative dynamics of Australiasian rabbit populations. Australian Wildlife Research 14, 491-503. doi:10.1071/WR9870491

Gonzalez, R. R., Kluger, M. J., and Hardy, J. D. (1971). Partitional calorimetry of the New Zealand white rabbit at temperatures $5^{\circ} \mathrm{C}-$ $25^{\circ} \mathrm{C}$. Journal of Applied Physiology 31, 728-734. doi:10.1152/jappl. 1971.31.5.728

Guillemette, C. U., Fletcher, Q. E., Boutin, S., Hodges, R. M., McAdam, A. G., and Humphries, M. M. (2009). Lactating squirrels experiencing high heat load occupy less insulated nests. Biology Letters 5, 166-168. doi: $10.1098 /$ rsbl.2008.0592

Hoy, S., and Selzer, D. (2010). Frequency and time of nursing in wild and domestic rabbits housed out-doors in free range. World Rabbit Science 10, 77-84.

Kasa, W., and Thwaites, C. J. (1990). The effects of elevated temperature and humidity on rectal temperature and respiration rate in the New Zealand white rabbit. International Journal of Biometeorology 34, 157-160. doi:10.1007/BF01048713

Kluger, M. J. (2012). Energy balance in the resting and exercising rabbit. In 'Perspectives in Biophysical Ecology'. (Eds D. M. Gates and R. B. Schmerl.) pp. 496-507. (Springer: Berlin.)

Król, E., and Speakman, J. R. (2003). Limits to sustained energy intake. VI. Energetics of lactation in laboratory mice at thermoneutrality. Journal of Experimental Biology 206, 4255-4266. doi:10.1242/jeb. 00674

Lebas, F. (1987). Influence de la taille de la portée et de la production laitière sur la quantité d'aliment ingérée par la lapine allaitante. Reproduction, Nutrition, Development 27, 207-208. doi:10.1051/rnd:19870214
Maertens, L., Lebas, F., and Szendro, Z. (2006). Rabbit milk: a review of quantity, quality and non-dietary affecting factors. World Rabbit Science 14, 205-230.

Myers, K. (1958). Further observations on the use of field enclosures for the study of wild rabbits, Oryctolagus cuniculus (L.). CSIRO Wildlife Research 3, 40-49. doi:10.1071/CWR9580040

Myers, K. (1971). The rabbit in Australia. In 'Dynamics of Populations'. (Eds P. J. den Boer and G. R. Gradwell.) pp. 478-506. (Centre for Agricultural Publishing and Documentation: Wageninen, Netherlands.)

Myers, K., and Gilbert, N. (1968). Determination of age of wild rabbits in Australia. The Journal of Wildlife Management 32, 841-849. doi: $10.2307 / 3799559$

Parigi-Bini, R., Xiccato, G., Cinetto, M., and Dalle Zotte, A. (1992). Energy and protein utilization and partition in does concurrently pregnant and lactating. Animal Science 55, 153-162.

Richardson, B. J., and Osborne, P. G. (1982). Experimental ecological studies on a subalpine rabbit population II. The effect of sodium and nutritional supplementation on breeding and physiological condition. Australian Wildlife Research 9, 451-463. doi:10.1071/WR9820451

Rödel, H. G., Valencak, T. G., Hendrek, A., and Monclús, R. (2015). Paying the energetic costs of reproduction: reliance on postpartum foraging and stored reserves. Behavioural Ecology 27, 748-756. doi:10.1093/beheco/arv217

Soriguer, R. C. (1981). Biología y dinámicas de una población de conejos (Oryctolagus cuniculus L.) en Andalucía Occidental. Doñana Acta Vertebrata 8, 1-379.

Stodart, E. (1965). A study of the biology of rabbits in climatically different regions of eastern Australia. III. Some data on the evolution of coat colour. CSIRO Wildlife Research 10, 73-82. doi:10.1071/CWR9650073

Stodart, E., and Parer, I. (1988). Colonization of Australia by the rabbit Oryctolagus cuniculus (L.). Project report no. 6. Division of Wildlife and Ecology, CSIRO, Canberra, ACT.

Tablado, Z., Revilla, E., and Palomares, F. (2009). Breeding like rabbits: global patterns of variability and determinants of European wild rabbit reproduction. Ecography 32, 310-320. doi:10.1111/j.1600-0587.2008. 05532.x

Valencak, T. G., Tataruch, F., and Ruf, T. (2009). Peak energy turnover in lactating European hares: the role of fat reserves. The Journal of Experimental Biology 212, 231-237. doi:10.1242/jeb.022640

Valencak, T. G., Wright, P., Weir, A., Mitchell, S. A., Vaanholt, L. M., Hambly, C., Król, E., and Speakman, J. R. (2013). Limits to sustained energy intake: XXI. Effect of exposing the mother, but not her pups, to a cold environment during lactation in mice. The Journal of Experimental Biology 216, 4326-4333. doi:10.1242/jeb.092023

Wells, K., O’Hara, R. B., Cooke, B. D., Mutze, G. J., Prowse, T. A., and Fordham, D. A. (2016). Environmental effects and individual body condition drive seasonal fecundity of rabbits: identifying acute and lagged processes. Oecologia 181, 853-864. doi:10.1007/s00442-016$3617-2$

West, J. W. (2003). Effects of heat-stress on production of dairy cattle. Journal of Dairy Science 86, 2131-2144. doi:10.3168/jds.S0022-0302 (03)73803-X

Williams, C. K., and Moore, R. J. (1989a). Genetic divergence in the fecundity of Australian wild rabbits Oryctolagus cuniculus. Journal of Animal Ecology 58, 249-259. doi:10.2307/4998

Williams, C. K., and Moore, R. J. (1989b). Phenotypic adaptation and natural selection in the wild rabbit Oryctolagus cuniculus, in Australia. Journal of Animal Ecology 58, 495-507. doi:10.2307/4844 